\title{
Changes in streamflow and sediment discharge and the response to human activities in the middle reaches of the Yellow River
}

\author{
P. Gao ${ }^{1,2}$, X.-M. Mu ${ }^{1,2}$, F. Wang ${ }^{1,2}$, and R. Li ${ }^{1,2}$ \\ ${ }^{1}$ Institute of Soil and Water Conservation, Northwest A\&F University, 26 Xinong Road, Yangling, 712100, \\ Shaanxi Province, China \\ ${ }^{2}$ Institute of Soil and Water Conservation, CAS and Ministry of Water Resources, 26 Xinong Road, Yangling, 712100, \\ Shaanxi Province, China
}

Received: 29 July 2010 - Published in Hydrol. Earth Syst. Sci. Discuss.: 8 September 2010

Revised: 10 December 2010 - Accepted: 21 December 2010 - Published: 3 January 2011

\begin{abstract}
The changes in streamflow and sediment discharge in the middle reaches of the Yellow River are a focus. In this paper, based on the precipitation, streamflow and sediment discharge series data (1950-2008), the streamflow and sediment discharge variation and its impact on precipitation/response to human activities have been analysis. The results show that significant decreasing trends in annual streamflow and sediment discharge have existed since the late 1950s in the middle reaches of the Yellow River $(P=0.01)$. Change-point analyses further revealed that transition years existed and that abrupt decline in streamflow and sediment discharge began in 1985 and 1981, respectively, in the middle reaches of the Yellow River $(P=0.05)$. Adoption of conservation measures in the 1980s and 1990s corroborates the identified transition years. Double-mass curves of precipitation vs. streamflow (sediment) for the periods before and after the transition year show remarkable decreases in proportionality of streamflow (sediment) generation. Compared with the period before the transition year, cumulative streamflow and cumulative sediment discharge reduced respectively by $17.8 \%$ and $28 \%$ during $1985-2008$, which was caused by human intervention, in the middle reaches of the Yellow River. It is, therefore, concluded that human activities occupied a dominant position and played a major role in the streamflow and sediment discharge reduction in the middle reaches of the Yellow River.
\end{abstract}

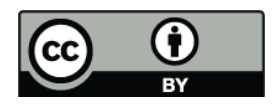

Correspondence to: P. Gao (gaopeng@ms.iswc.ac.cn)

\section{Introduction}

Streamflow and sediment discharge provide useful information on the processes of soil erosion and sediment delivery occurring in a basin (Siakeu et al., 2004). The middle reaches of the Yellow River flows through the Loess Plateau. Due to improper land use and excessive exploitation, the Loess Plateau is counted among the most severely eroded areas in the world. Meanwhile, rivers in this region transport a large amount of sediment to the Yellow River and, therefore, the middle reaches become the main source area of Yellow River sediment. The water from the middle reaches accounted for $44.3 \%$ of the Yellow River streamflow, but the sediment has accounted for $88.2 \%$ of the Yellow River sediment. Since the 1950s, many soil conservation measures have been implemented in the Yellow River basin, which included the construction of terraces, dams and reservoirs, conversion of croplands to grasslands and woodlands, and vegetation restoration (Lee, 1984; Yu, 2006; Zheng et al., 2007). The streamflow and sediment began to reduce in the 1970s and there was a sharp decline since the 1980s in the middle reaches of the basin. Compared with the period of 1950-1969, the average annual sediment discharge reduced about $5 \times 10^{8} \mathrm{t}$ during $1980-1999$, and the rate of decrease is $43.6 \%$. The average annual streamflow reduced about $101 \times 10^{8} \mathrm{~m}^{3}$, and the rate of decrease is $42.6 \%$.

Recent studies have shown that streamflow and sediment discharge of the Yellow River decreased since the late 1950s (Yu, 2006). Fu et al. (2007) stated that climate variability had a significant impact on streamflow in the Yellow River and that streamflow was sensitive to both precipitation and

Published by Copernicus Publications on behalf of the European Geosciences Union. 


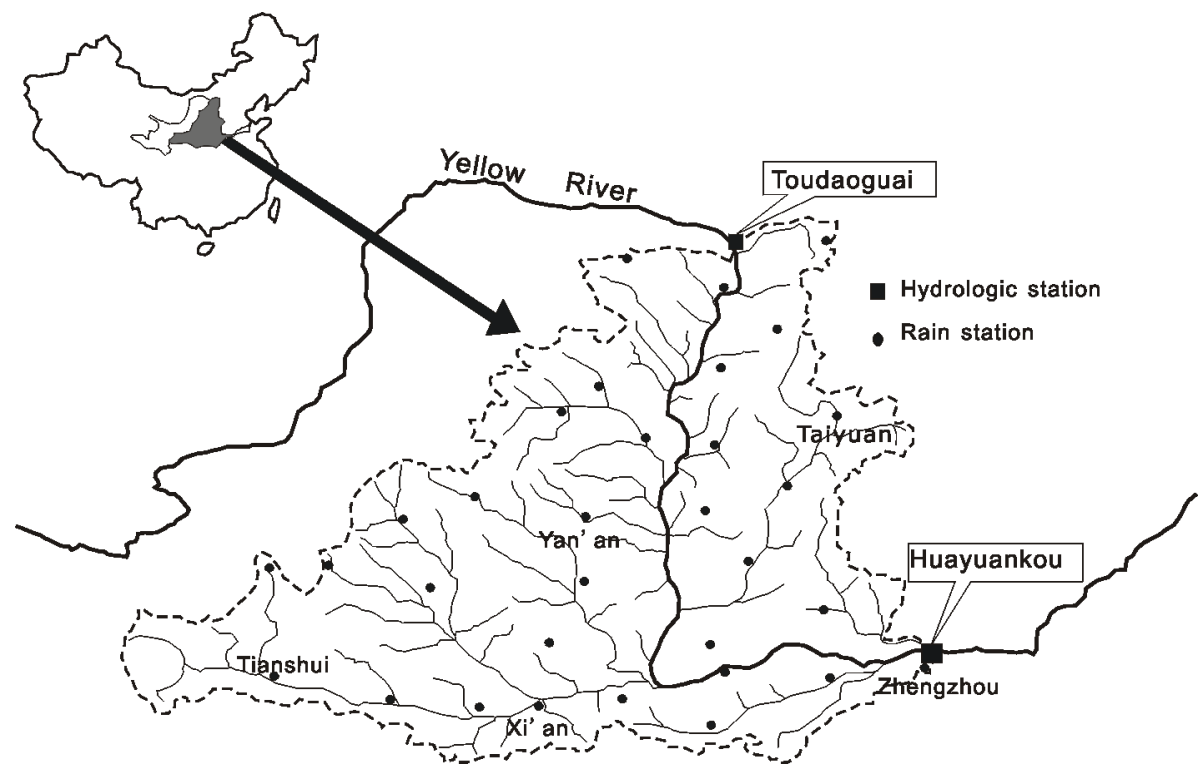

Fig. 1. Location of the study region and stations in the middle reaches of the Yellow River basin.

temperature in the basin. Wang et al. (2007) found that a decrease in precipitation is responsible for $30 \%$ of the decrease in sediment discharge at Huayuankou, while the remaining $70 \%$ is ascribed to human activities in the river basin. Li et al. (2007) and Gao et al. (2009) studied annual streamflow and sediment discharge in the Wuding River (a tributary in the middle reaches of the Yellow River) and reported that there was a significant downward trend.

Although there have been many publications, especially in Chinese literature, that discussed the decreases in streamflow and sediment discharge in the Yellow River over the past 50 years (Tang, 1993; Ye et al., 1994), most of them focus mainly on the descriptive amount of decreases in streamflow and sediment discharge recorded, rather than quantitative analyses. The magnitudes of the decreases have not yet been fully quantified and statistically tested in a systematic manner for neither middle reaches nor the entire basin. The downward trends need to be statistically tested in order to discern whether they are random fluctuations or tendency variations. If a downward trend exists, it is important and necessary to further check exactly when the change began and what the driving factors are. Understanding the impacts of climate variation and human activity on hydrological regime and sediment dynamics is useful for developing effective conservation strategies in the middle reaches of the Yellow River basin. Therefore, the objectives of this study are: (a) to statistically detect trends and change-points in annual streamflow and sediment discharge in the middle reaches of the Yellow River basin; (b) to analyse possible impacts of precipitation and human activities on annual streamflow and sediment discharge dynamics in relation to changepoints or transition years detected in this study; and (c) to further estimate the effects of the identified driving factors on both streamflow and sediment discharge decline by comparing two contrasting periods before and after the transition years.

\section{Study area and data sets}

The middle reaches of the Yellow River (MRYR), between Toudaoguai and Huayuankou, is the study region of this paper. The region area is $344000 \mathrm{~km}^{2}$ between $104^{\circ} \mathrm{E}-113^{\circ} \mathrm{E}$ and $32^{\circ} \mathrm{N}-42^{\circ} \mathrm{N}$.

A data set from 33 meteorological stations with long-term annual precipitation data (1957-2008) in the MRYR basin was analysed in this study (Fig. 1 and Table 1). The precipitation data were provided by The National Meteorological Information Centre (NMIC), China Meteorological Administration (CMA). Two key hydrological stations in the MRYR mainstream (Toudaoguai and Huayuankou) were chosen to calculate the streamflow and sediment discharge in the region for analysis (Fig. 1 and Table 1). Annual streamflow and sediment discharge data at the two stations from 1950 to 2008 were obtained from the Chinese River Streamflow and Sediment Communiques, the Ministry of Water Resources of PRC (MWR). All measured data used in this study are of good quality and were checked for quality control by corresponding agencies. 
Table 1. The location and data series of the hydrologic and rain station.

\begin{tabular}{lrrr}
\hline Station & Longitude(E) & Latitude(N) & Series(Year) \\
\hline Toudaoguai & $111^{\circ} 02^{\prime}$ & $40^{\circ} 17^{\prime}$ & $1950-2008$ \\
Huayuankou & $113^{\circ} 40^{\prime}$ & $35^{\circ} 54^{\prime}$ & $1950-2008$ \\
Xiji & $105^{\circ} 43^{\prime}$ & $35^{\circ} 58^{\prime}$ & $1958-2008$ \\
Tianshui & $105^{\circ} 45^{\prime}$ & $34^{\circ} 35^{\prime}$ & $1957-2008$ \\
Guyuan & $106^{\circ} 16^{\prime}$ & $36^{\circ} 00^{\prime}$ & $1957-2008$ \\
Baoji & $107^{\circ} 08^{\prime}$ & $34^{\circ} 21^{\prime}$ & $1957-2008$ \\
Huanxian & $107^{\circ} 18^{\prime}$ & $36^{\circ} 35^{\prime}$ & $1957-2008$ \\
Xifeng & $107^{\circ} 38^{\prime}$ & $35^{\circ} 44^{\prime}$ & $1957-2008$ \\
Changwu & $107^{\circ} 48^{\prime}$ & $35^{\circ} 12^{\prime}$ & $1957-2008$ \\
Wuqi & $108^{\circ} 11^{\prime}$ & $36^{\circ} 50^{\prime}$ & $1957-2008$ \\
Wugong & $108^{\circ} 13^{\prime}$ & $34^{\circ} 15^{\prime}$ & $1957-2008$ \\
Xi'an & $108^{\circ} 56^{\prime}$ & $34^{\circ} 18^{\prime}$ & $1957-2008$ \\
Tongchuan & $109^{\circ} 04^{\prime}$ & $35^{\circ} 05^{\prime}$ & $1957-2008$ \\
Hengshan & $109^{\circ} 14^{\prime}$ & $37^{\circ} 56^{\prime}$ & $1957-2008$ \\
Luochuan & $109^{\circ} 30^{\prime}$ & $35^{\circ} 49^{\prime}$ & $1957-2008$ \\
Yan'an & $109^{\circ} 30^{\prime}$ & $36^{\circ} 36^{\prime}$ & $1957-2008$ \\
Yulin & $109^{\circ} 42^{\prime}$ & $38^{\circ} 14^{\prime}$ & $1957-2008$ \\
Dongsheng & $109^{\circ} 59^{\prime}$ & $39^{\circ} 50^{\prime}$ & $1957-2008$ \\
Huashan & $110^{\circ} 05^{\prime}$ & $34^{\circ} 29^{\prime}$ & $1957-2008$ \\
Suide & $110^{\circ} 13^{\prime}$ & $37^{\circ} 30^{\prime}$ & $1957-2008$ \\
Xixian & $110^{\circ} 57^{\prime}$ & $36^{\circ} 42^{\prime}$ & $1957-2008$ \\
Yuncheng & $111^{\circ} 01^{\prime}$ & $35^{\circ} 02^{\prime}$ & $1957-2008$ \\
Lushi & $111^{\circ} 02^{\prime}$ & $34^{\circ} 03^{\prime}$ & $1957-2008$ \\
Lishi & $111^{\circ} 06^{\prime}$ & $37^{\circ} 30^{\prime}$ & $1957-2008$ \\
Xingxian & $111^{\circ} 08^{\prime}$ & $38^{\circ} 28^{\prime}$ & $1957-2008$ \\
Hequ & $111^{\circ} 09^{\prime}$ & $39^{\circ} 23^{\prime}$ & $1957-2008$ \\
\hline
\end{tabular}

\section{Analysis methods}

\subsection{Trend test}

The rank-based, non-parametric Mann-Kendall statistical test (Mann, 1945; Kendall, 1975) is commonly used for trend detection due to its robustness for non-normally distributed and censored data, which are frequently encountered in hydroclimatic time series (e.g., Hirsch et al., 1982; Burn and Elnur, 2002; Yue et al., 2003; Yue and Pilon, 2004).

The results of the trend test can be used to determine whether or not the observed time series of hydrological variables exhibits a trend that is statistically significant from a trend that could occur by chance; and to do this, it is necessary to test the serial correlation of the data (Jenkins and Watts, 1968). However, the presence of serial correlation can complicate the identification of trends, in that a positive serial correlation can increase the expected number of false positive outcomes for the Mann-Kendall test (von Storch and Navarra, 1995). Thus, any serial correlation should be removed before conducting the Mann-Kendall trend test. In this work the trend-free pre-whitening (TFPW) method of Yue et al. (2003) was used as follows.
Firstly, remove any significant linear trend from the raw time series using:

$Y_{\mathrm{t}}=X_{\mathrm{t}}-\beta t$

where $X_{\mathrm{t}}$ is the series value at time $t ; \beta$ is the linear regression slope of the trend in the raw time series, $Y_{\mathrm{t}}$ is the detrended series.

Secondly, remove serial correlation if the lag-one serial correlation coefficient $\left(r_{1}\right)$ of the de-trended series is statistically significant at the 5\% level, using the pre-whitening method of Kulkarni \& von Storch (1995):

$Y_{\mathrm{t}}^{\prime}=Y_{\mathrm{t}}-r_{1} Y_{t-1}$

where $Y_{\mathrm{t}}^{\prime}$ is the de-trended and pre-whitened series, which is referred to as the residual series.

Thirdly, add the linear trend that was removed at step 1 back to the de-trended or residual series, using:

$Y_{\mathrm{t}}^{\prime \prime}=Y_{\mathrm{t}}^{\prime}+\beta t$

where $Y_{t}^{\prime \prime}$ is the trend-free pre-whitened series.

$\mathrm{Z}$ statistic was obtained from the Mann-Kendall test on the whitened series from TFPW method. In addition, to confirm the results provided by the Mann-Kendall test, we also performed linear regression analysis.

\subsection{Change-point analysis}

A number of methods can be applied to determine change points of a time series (Buishand, 1982; Chen and Gupta, 2000; Radziejewski et al., 2000). In this study, we used the non-parametric approach developed by Pettitt (1979) to detect change-points in streamflow and sediment discharge time-series. This method detects a significant change in the mean of a time series when the exact time of the change is unknown. The test uses a version of the Mann-Whitney statistic $U_{\mathrm{t}, \mathrm{N}}$, that tests whether two sample sets $x_{1}, \ldots x_{\mathrm{t}}$ and $x_{\mathrm{t}+1}, \ldots$ $x_{\mathrm{N}}$ are from the same population. The test statistic $U_{\mathrm{t}, \mathrm{N}}$ is given by:

$U_{\mathrm{t}, \mathrm{N}}=U_{\mathrm{t}-1, \mathrm{~N}}+\sum_{\mathrm{j}=1}^{N} \operatorname{sgn}\left(X_{\mathrm{t}}-X_{\mathrm{j}}\right) \quad$ for $\quad t=2, \ldots, N$

and

$\begin{array}{ll}\text { if }\left(X_{\mathrm{t}}-X_{\mathrm{j}}\right)>0, & \operatorname{sgn}\left(X_{\mathrm{t}}-X_{\mathrm{j}}\right)=1 \\ \text { if }\left(X_{\mathrm{t}}-X_{\mathrm{j}}\right)=0, & \operatorname{sgn}\left(X_{\mathrm{t}}-X_{\mathrm{j}}\right)=0 \\ \text { if }\left(X_{\mathrm{t}}-X_{\mathrm{j}}\right)<0, & \operatorname{sgn}\left(X_{\mathrm{t}}-X_{\mathrm{j}}\right)=-1\end{array}$

The test statistic counts the number of times a member of the first sample exceeds a member of the second sample. The null hypothesis of the Pettitt's test is the absence of a change point. The test statistic $K_{\mathrm{N}}$ and the associated probability $(P)$ used in the test are given as:

$$
\begin{aligned}
& K_{\mathrm{N}}=\max _{1 \leq t \leq N}\left|U_{\mathrm{t}, \mathrm{N}}\right| \\
& \mathrm{P} \cong 2 \exp \left\{-6\left(K_{\mathrm{N}}\right)^{2} /\left(N^{3}+N^{2}\right)\right\}
\end{aligned}
$$


Table 2. Characteristics of precipitation, streamflow and sediment discharge in different decades in the MRYR basin.

\begin{tabular}{lrrr|rrr|rrrr}
\hline & \multicolumn{3}{c}{ Precipitation $(\mathrm{mm})$} & \multicolumn{3}{c}{ Streamflow $\left(10^{8} \mathrm{~m}^{3}\right)$} & \multicolumn{2}{c}{ Sediment discharge $\left(10^{8} \mathrm{t}\right)$} \\
\cline { 2 - 10 } Series & Average & $\begin{array}{r}\text { Extremum } \\
\text { ratio }\end{array}$ & $\mathrm{C}_{\mathrm{V}}$ & Average & $\begin{array}{r}\text { Extremum } \\
\text { ratio }\end{array}$ & $\mathrm{C}_{\mathrm{V}}$ & $\begin{array}{r}\text { Average } \\
\text { Extremum } \\
\text { ratio }\end{array}$ & $\mathrm{C}_{\mathrm{V}}$ \\
\hline $1950 \mathrm{~s}$ & 564.21 & 1.48 & 0.20 & 240.06 & 2.40 & 0.29 & 14.08 & 3.76 & 0.47 \\
$1960 \mathrm{~s}$ & 561.28 & 2.05 & 0.21 & 234.97 & 36.98 & 0.50 & 9.31 & 10.47 & 0.61 \\
$1970 \mathrm{~s}$ & 510.12 & 1.45 & 0.11 & 148.38 & 2.43 & 0.28 & 11.21 & 3.25 & 0.39 \\
$1980 \mathrm{~s}$ & 515.55 & 1.64 & 0.14 & 172.62 & 3.01 & 0.36 & 6.77 & 5.39 & 0.49 \\
$1990 \mathrm{~s}$ & 474.52 & 1.64 & 0.15 & 100.14 & 3.95 & 0.38 & 6.43 & 2.87 & 0.37 \\
$2000 \mathrm{~s}$ & 488.87 & 1.60 & 0.17 & 87.28 & 6.26 & 0.44 & 0.72 & 14.52 & 0.88 \\
\hline $1950-2008$ & 511.41 & 2.05 & 0.17 & 165.21 & 36.98 & 0.53 & 8.21 & 212.66 & 0.72 \\
\hline
\end{tabular}

Table 3. Results of trend analysis for annual precipitation, streamflow and sediment discharge in the MRYR basin during 1950-2008.

\begin{tabular}{lrr|rr}
\hline \multirow{2}{*}{ Variable } & \multicolumn{2}{c|}{ Mann-Kendall } & \multicolumn{2}{c}{ Linear regression } \\
& $Z$ statistic & Sig. level & $t$ statistic & Sig. level \\
\hline Precipitation & -2.344 & 0.05 & -2.235 & 0.05 \\
Streamflow & -5.071 & 0.01 & -5.806 & 0.01 \\
Sediment discharge & -5.474 & 0.01 & -5.735 & 0.01 \\
\hline
\end{tabular}

A negative sign indicates a decreasing trend.

\subsection{Double mass curve}

Double mass curve is a simple, visual and practical method, and it is widely used in the study of the consistency and long-term trend test of hydrometeo-rological data $(\mathrm{Mu}$, et al., 2010). This method was first used to analyze the consistency of precipitation data in Susquehanna watershed United States by Merriam at 1937 (Merriam, 1937), and Searcy made a theoretical explanation of it (Searcy et al., 1960). The theory of the double-mass curve is based on the fact that a plot of the two cumulative quantities during the same period exhibits a straight line so long as the proportionality between the two remains unchanged, and the slope of the line represents the proportionality. This method can smooth a time series and suppress random elements in the series, and thus show the main trends of the time series. In recent 30 years, Chinese scholars analyzed the effect of soil and water conservation measures and land use/cover changes on runoff and sediment using double mass curve method, and have achieved good results (Mu, et al., 2010). In this study, double-mass curves of precipitation vs. streamflow and precipitation vs. sediment are plotted for the two different periods to estimate changes in regression slope (proportionality) to quantify the overall efficiency of soil conservation measures before and after transition years.

\section{Results and discussion}

\subsection{Trend analysis of observed annual precipitation, streamflow and sediment discharge}

The characteristics of precipitation, streamflow and sediment discharge in different decades in the MRYR are given in Table 2. The annual average precipitation, streamflow and sediment discharge is $511.41 \mathrm{~mm}, 165.21 \times 10^{8} \mathrm{~m}^{3}$ and $8.21 \times 10^{8} \mathrm{t}$, respectively; and the coefficient of variation $\left(\mathrm{C}_{\mathrm{V}}\right)$ is $0.17,0.53$ and 0.72 , respectively, in the MRYR during 1950-2008.

The observed annual precipitation, streamflow and sediment discharge during 1950-2008 in the MRYR are shown in Fig. 2, and their corresponding Mann-Kendall test results are given in Table 3. The streamflow and sediment discharge decreased significantly, with average annual decrease rate being $-3.21 \times 10^{8} \mathrm{~m}^{3} / \mathrm{a}$ and $-0.21 \times 10^{8} \mathrm{t} / \mathrm{a}$, respectively. The precipitation showed a downward trend, with average annual decrease rate being $-1.69 \mathrm{~mm} / \mathrm{a}$.

\subsection{Change-point analysis}

Since the Mann-Kendall tests showed significant downward trends in precipitation, streamflow and sediment discharge, the Pettitt's test was further used to detect the change points or transition years (Fig. 2). For annual precipitation, there is no change-point year could be detected at $P=0.05$. For annual streamflow, the change-point year was detected in $1985(P=0.01)$, it was $205.9 \times 10^{8} \mathrm{~m}^{3}$ and $101.5 \times 10^{8} \mathrm{~m}^{3}$ respectively in the periods before and after 1985 . For annual sediment discharge, the change-point year was detected in $1981(P=0.01)$. Sediment discharge was $11.3 \times 10^{8} \mathrm{t}$ and $4.5 \times 10^{8} \mathrm{t}$ respectively during $1950-1981$ and 1981-2008. 
Table 4. Linear regression equations between cumulative streamflow and cumulative precipitation for the period before the transition years in the MRYR basin.

\begin{tabular}{lrrrr}
\hline Regression equation & $R_{\mathrm{c}}\left(10^{8} \mathrm{~m}^{3}\right)$ & $R_{\mathrm{O}}\left(10^{8} \mathrm{~m}^{3}\right)$ & $R_{\mathrm{c}}-R_{\mathrm{O}}\left(10^{8} \mathrm{~m}^{3}\right)$ & $100 \times\left(R_{\mathrm{c}}-R_{\mathrm{o}}\right) / R_{\mathrm{c}}(\%)$ \\
\hline$\sum R=0.3601 \sum P+203.21\left(R^{2}=0.9891, N=29\right)$ & 9779.41 & 8040.30 & 1739.11 & 17.8 \\
\hline
\end{tabular}

$\Sigma R$ : cumulative streamflow; $\Sigma P$ : cumulative precipitation; $R_{\mathrm{c}}$ : extrapolated cumulative streamflow till 2008; $R_{\mathrm{O}}$ : observed cumulative streamflow till 2008 .

Table 5. Linear regression equations between cumulative sediment discharge and cumulative precipitation for the period before the transition years in the MRYR basin.

\begin{tabular}{lrrrr}
\hline Regression equation & $S_{\mathrm{c}}\left(10^{8} \mathrm{t}\right)$ & $S_{\mathrm{o}}\left(10^{8} \mathrm{t}\right)$ & $S_{\mathrm{c}}-S_{\mathrm{o}}\left(10^{8} \mathrm{t}\right)$ & $100 \times\left(S_{\mathrm{c}}-S_{\mathrm{o}}\right) / S_{\mathrm{c}}(\%)$ \\
\hline$\sum S=0.0207 \sum P+1.2069\left(R^{2}=0.9915, N=25\right)$ & 551.69 & 397.23 & 154.46 & 28.0 \\
\hline
\end{tabular}

$\Sigma S$ : cumulative sediment discharge; $\Sigma P$ : cumulative precipitation; $S_{\mathrm{c}}$ : extrapolated cumulative sediment discharge till $2008 ; S_{\mathrm{O}}:$ observed cumulative sediment discharge till 2008 .

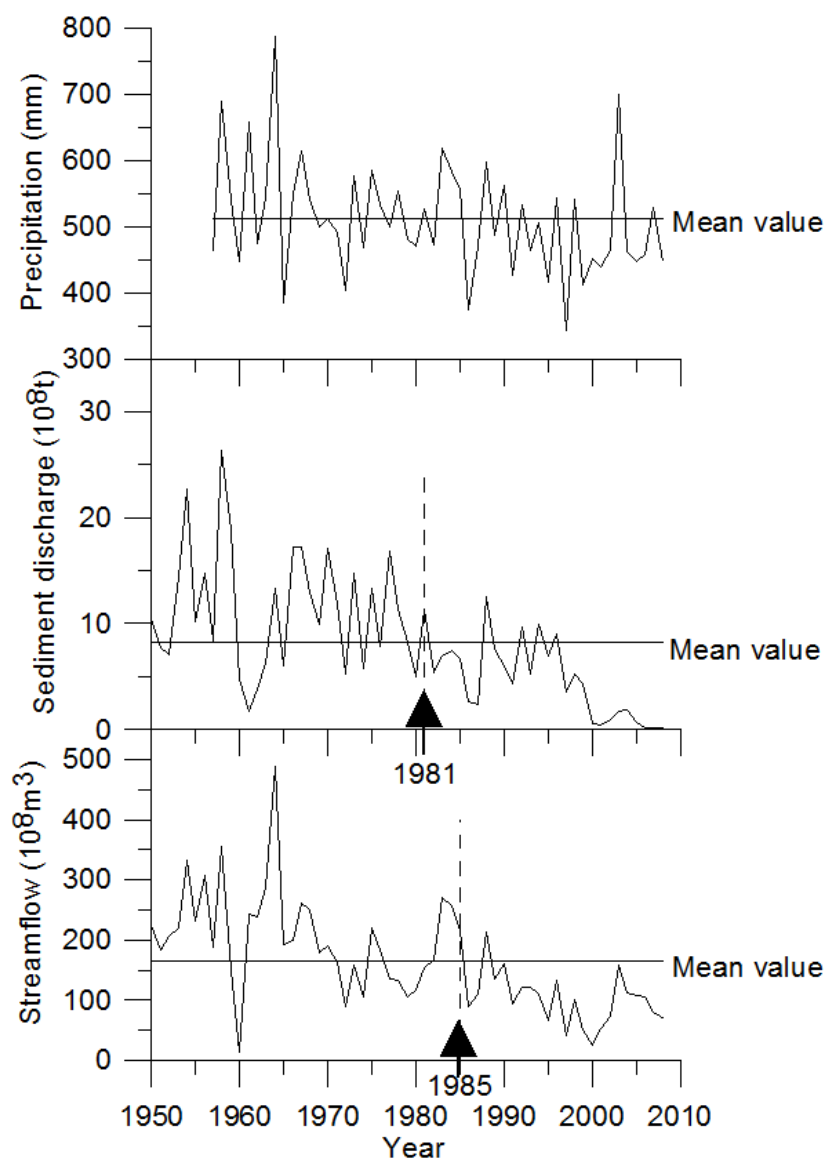

Fig. 2. Observed annual precipitation, streamflow and sediment discharge during 1950-2008 in the MRYR basin. The black arrow is change-point year.

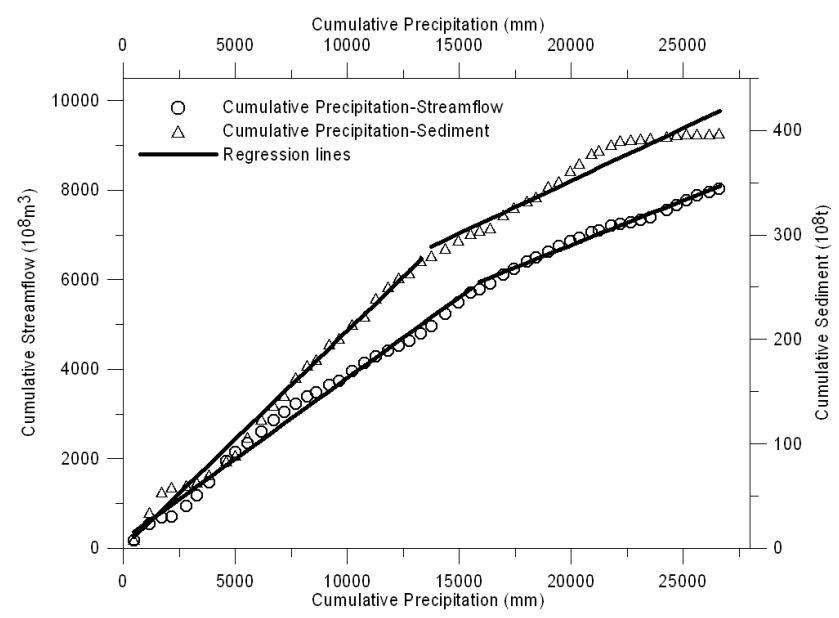

Fig. 3. Double mass curves of precipitation-streamflow and precipitation-sediment during 1957-2008 in the MRYR.

\subsection{Double mass curve of precipitation-streamflow and precipitation-sediment}

To further quantify the streamflow and sediment discharge changes before and after the transition years, double mass curves, along with the linear regression lines, were plotted in Fig. 3. There existed clear breakpoints between the two regression lines for both streamflow and sediment discharge in the basin, suggesting that the transition years, identified by Pettitt's method, are correct and meaningful. The slopes of the regression lines were lower after the breakpoints or transition years (i.e. at higher cumulative precipitation values) than before for both streamflow and sediment discharge in the basin. To estimate the relative reduction of total streamflow and sediment discharge for the period after the transition years, the information of these two factors and precipitation 
Table 6. The impact of precipitation and human intervention on annual streamflow decline in the MRYR basin.

\begin{tabular}{|c|c|c|c|c|c|c|c|c|}
\hline \multirow[t]{3}{*}{ Period } & \multirow{3}{*}{$\begin{array}{r}R_{\mathrm{ao}} \\
\left(10^{8} \mathrm{~m}^{3}\right)\end{array}$} & \multirow{3}{*}{$\begin{array}{r}R_{\mathrm{co}} \\
\left(10^{8} \mathrm{~m}^{3}\right)\end{array}$} & \multicolumn{2}{|c|}{$\Delta R$} & \multicolumn{2}{|c|}{ Impact of precipitation } & \multicolumn{2}{|c|}{ Impact of human intervention } \\
\hline & & & Amount & Percentage & Amount & Percentage & Amount & Percentage \\
\hline & & & $\left(10^{8} \mathrm{~m}^{3}\right)$ & $(\%)$ & $\left(10^{8} \mathrm{~m}^{3}\right)$ & $(\%)$ & $\left(10^{8} \mathrm{~m}^{3}\right)$ & $(\%)$ \\
\hline Before 1985 & 196.77 & 199.70 & & & & & & \\
\hline 1986-1989 & 136.80 & 173.72 & 59.97 & 30.5 & 23.04 & 38.4 & 36.92 & 61.6 \\
\hline 1990-1999 & 100.14 & 170.87 & 96.63 & 49.1 & 25.89 & 26.8 & 70.73 & 73.2 \\
\hline $2000-2008$ & 87.28 & 176.04 & 109.49 & 55.6 & 20.72 & 18.9 & 88.77 & 81.1 \\
\hline
\end{tabular}

$R_{\mathrm{ao}}$ : observed annual average streamflow; $R_{\mathrm{co}}$ : calculated annual average streamflow; $\Delta R$ : reduction in observed streamflow comparing with the period of $1950-1985$.

Table 7. The impact of precipitation and human intervention on annual sediment discharge decline in the MRYR basin.

\begin{tabular}{|c|c|c|c|c|c|c|c|c|}
\hline \multirow[t]{3}{*}{ Period } & \multirow{3}{*}{$\begin{array}{r}S_{\mathrm{ao}} \\
\left(10^{8} \mathrm{t}\right)\end{array}$} & \multirow{3}{*}{$\begin{array}{r}S_{\mathrm{co}} \\
\left(10^{8} \mathrm{t}\right)\end{array}$} & \multicolumn{2}{|c|}{$\Delta S$} & \multicolumn{2}{|c|}{ Impact of precipitation } & \multicolumn{2}{|c|}{ Impact of human intervention } \\
\hline & & & Amount & Percentage & Amount & Percentage & Amount & Percentage \\
\hline & & & $\left(10^{8} \mathrm{t}\right)$ & $(\%)$ & $\left(10^{8} \mathrm{t}\right)$ & $(\%)$ & $\left(10^{8} \mathrm{t}\right)$ & $(\%)$ \\
\hline Befor 1981 & 11.00 & 11.05 & & & & & & \\
\hline 1982-1989 & 6.42 & 10.76 & 4.59 & 41.7 & 0.24 & 5.3 & 4.34 & 94.7 \\
\hline 1990-1999 & 6.43 & 9.82 & 4.58 & 41.6 & 1.18 & 25.8 & 3.39 & 74.2 \\
\hline 2000-2008 & 0.72 & 10.12 & 10.28 & 93.4 & 0.88 & 8.6 & 9.40 & 91.4 \\
\hline
\end{tabular}

$S_{\text {ao }}$ : observed annual average sediment discharge; $S_{\mathrm{co}}$ : calculated annual average sediment discharge; $\Delta S$ : reduction in observed sediment discharge comparing with the period of 1950-1981.

before the transition years were used to establish regression equations (Tables 4 and 5), and to further extrapolate the cumulative streamflow and sediment up until 2008. The extrapolated cumulative streamflow ( $R_{\mathrm{c}}$ in Table 4$)$ and sediment discharge ( $S_{\mathrm{c}}$ in Table 5 ) were based on the assumption that environmental conditions, including human impacts in the basin in the first period before the transition years, remained unchanged in the second period after the transition years. Compared with the extrapolated cumulative streamflow $\left(R_{\mathrm{c}}\right)$, observed cumulative streamflow $\left(R_{\mathrm{O}}\right.$ in Table 4$)$ reduced by $17.8 \%$ in the basin (Table 4$)$. The corresponding reduction for sediment discharge was $28.0 \%$ in the basin (Table 5). It should be noted that the percent reductions in cumulative sediment discharge were greater than those in cumulative streamflow.

\subsection{Impacts of precipitation and human intervention}

We can calculated the annual streamflow and sediment discharge for the period after the transition years using the regression equations established from the double mass curve of precipitation-streamflow and precipitation-sediment before the transition years. The difference between the calculated values in different periods is because of the impact of precipitation changes. However, the difference between the calculated values and measured values in the same period is the result of human activities. The results were shown in Tables 6 and 7.
For the streamflow reduction, the impact of human activities showed an increasing trend from $61.6 \%$ in the 1980 s to $81.1 \%$ in the early 21 st century (in Table 6), and it had been the dominant factor ever since the transition year. And the average human activities contribution rate is $72.0 \%$ from 1986 to 2008 , which is significantly stronger than the contribution rate of precipitation $(28 \%)$. On the other hand, the impact of human activity was also the main factor in the sediment discharge decline after the transition year; although this effect weakened in the 1990s. The average human activities contribution rate is $87.8 \%$ from $1982-2008$, which is still significantly stronger than the contribution rate of precipitation $(12.2 \%)$. The analysis showed that: human activities played a major role in the streamflow and sediment discharge reduction in the MRYR basin.

\subsection{Influence of human activities on streamflow and sediment discharge decline}

Many studies have documented that human and economic activities (especially after the 1980s) might play an important role in streamflow and sediment discharge reduction in the Yellow River basin (van den Elsen et al., 2003; Xu, 2003; Huang and Zhang, 2004; Mu et al., 2007; Gao et al., 2010). Those activities can be summarized as follows:

a. Increased demand for water resources in the Yellow River due to national economic development. With 
Table 8. Land areas of major conservation practices and percentage area under control measures in different periods in the Loess Plateau in the MRYR basin.

\begin{tabular}{lrrrrr}
\hline & \multicolumn{5}{c}{ Increment in controlled area in different periods } \\
\cline { 2 - 6 } Control measures & $1950-1955$ & $1956-1965$ & $1966-1978$ & $1979-1989$ & $1989-1997$ \\
\hline Bench terrace $\left(\mathrm{km}^{2}\right)$ & 868.3 & 4540.5 & 19892.3 & 11124.3 & 22816.3 \\
Farmland in check dam $\left(\mathrm{km}^{2}\right)$ & 33.3 & 318.6 & 1563.7 & 822.6 & 763.0 \\
Afforestation $\left(\mathrm{km}^{2}\right)$ & 490.8 & 6090.3 & 19443.9 & 32622.7 & 37587.3 \\
Grass planting $\left(\mathrm{km}^{2}\right)$ & 689.7 & 1579.2 & 2731.3 & 13979.5 & 2858.5 \\
Total conservation area $\left(\mathrm{km}^{2}\right)$ & 2082.1 & 12528.7 & 43631.2 & 58549.2 & 64025.1 \\
Cumulative conservation area $\left(\mathrm{km}^{2}\right)$ & 2082.1 & 14610.7 & 58241.9 & 116791.1 & 180816.2 \\
Cumulative area under conservation $(\%)$ & 0.5 & 3.3 & 13.2 & 26.5 & 41.1 \\
\hline
\end{tabular}

Table 9. The results of sediment discharge and streamflow reduction through soil and water conservation measures in different periods in the MRYR.

\begin{tabular}{lcc}
\hline Period & Reduced water $\left(10^{8} \mathrm{~m}^{3} / \mathrm{a}\right)$ & Reduced sediment $\left(10^{8} \mathrm{t} / \mathrm{a}\right)$ \\
\hline $1970-1979$ & 4.54 & 1.99 \\
$1980-1989$ & 5.70 & 2.23 \\
$1990-1996$ & 6.41 & 2.61 \\
$1970-1996$ & 5.46 & 2.24 \\
\hline
\end{tabular}

the rapid development of China's national economy, water extraction and diversion has dramatically increased for agricultural irrigation and urban and industrial use, especially after the 1980s (Liu and Zhang, 2004). The average annual water extraction and diversion was $64.01 \times 10^{8} \mathrm{~m}^{3}$ during $1998-2007$, accounting for $38.75 \%$ of average annual streamflow in the MRYR basin.

b. Impact of soil and water conservation programs and ecological environment rehabilitation campaign in the Loess Plateau. The Loess Plateau, situated in the MRYR basin, is the major sediment source area for the river. To reduce water and soil erosion, some water and soil conservation measures were implemented between 1950 and 1978 (Mu et al., 2007). However, a large-scale of soil and water conservation measures were carried out between 1979 and 1997 due to various governmentsponsored conservation programmes and environmental rehabilitation campaigns in the MRYR basin. Until 1978, different types of conservation measures covered $13.2 \%$ of the basin, and the percentage increased to $41.1 \%$ in 1997 . Based on the average area that received conservation measures per year, the increasing rates of terrace building, check dam construction, afforestation, and grass planting during 1979-1997 were
2.1, 1.3, 4.1 and 5.1 times the rates during 1950-1978 (Table 8) (Gao, 2010). By 2006, about $49 \%$ of eroded land had been control, with sorts of soil and water conservation measures (including $52729 \mathrm{~km}^{2}$ of prime farmlands, $94613 \mathrm{~km}^{2}$ of soil and water conservation forest and $34938 \mathrm{~km}^{2}$ of grass planting), more than 2700 structures of key projects for gully erosion control and more than 4300000 structures of assisted small- scale projects in the Loess Plateau. Undoubtedly, the rapid adoption of soil and water conservation measures and engineering structures in the 1980s and 1990s played a significant role in streamflow and sediment discharge reduction in the Loess Plateau in the MRYR. The results of sediment discharge and streamflow reduction through soil and water conservation measures in different periods in the MRYR were shown in Table 9, and the effects of those measures showed an increasing trend over time (Ran, 2006). This rapid adoption period is in good agreement with the transition year of sediment discharge (1981) identified by the change-point analysis, suggesting that the conservation effects on streamflow reduction may have a time lag in such a large basin.

c. Impact of the construction of water control projects. Construction of large/medium-sized multi-purpose water control projects has some effect on streamflow and sediment discharge decline in the Yellow River (Tian et al., 2005; Wang et al., 2005). The evaporation and leakage losses from the reservoir was about $10.04 \times 10^{8} \mathrm{~m}^{3} / \mathrm{a}$, accounting for $6.08 \%$ of average annual streamflow in the MRYR basin. Reservoir siltation, though undesirable, has reduced sediment discharge in the MRYR basin. There were four large/medium-sized multi-purpose water control projects including Wanjiazhai, Tianqiao, Sanmenxia and Xiaodangdi in the mainstream. These reservoirs, facing various degrees of siltation problems, had reduced sediment discharge in downstream region. In almost 50 years, these four 
Table 10. The results of reduced water estimated in the MRYR basin.

\begin{tabular}{lcccc}
\hline $\begin{array}{l}\text { Calculated reduced } \\
\text { streamfllow }\left(10^{8} \mathrm{~m}^{3} / \mathrm{a}\right)\end{array}$ & \multicolumn{4}{c}{ Human activities impact on reduced water } \\
\cline { 2 - 5 } & $\begin{array}{c}\text { Total } \\
\left(10^{8} \mathrm{~m}^{3} / \mathrm{a}\right)\end{array}$ & $\begin{array}{c}\text { Water extraction } \\
\text { and diversion } \\
\left(10^{8} \mathrm{~m}^{3} / \mathrm{a}\right)\end{array}$ & $\begin{array}{c}\text { Soil and water } \\
\text { conservation measures } \\
\left(10^{8} \mathrm{~m}^{3} / \mathrm{a}\right)\end{array}$ & $\begin{array}{c}\text { Evaporation and } \\
\text { leakage losses } \\
\left(10^{8} \mathrm{~m}^{3} / \mathrm{a}\right)\end{array}$ \\
\hline 72.5 & 61.0 & 45.0 & 10.0 & 6.0 \\
\hline
\end{tabular}

Table 11. The results of sediment reduction estimated in the MRYR basin.

\begin{tabular}{lcccc}
\hline $\begin{array}{l}\text { Calculated reduced } \\
\text { Sediment }\left(10^{8} \mathrm{t} / \mathrm{a}\right)\end{array}$ & \multicolumn{4}{c}{ Human activites impact on sediment } \\
\cline { 2 - 5 } & $\begin{array}{c}\text { Total } \\
\left(10^{8} \mathrm{t} / \mathrm{a}\right)\end{array}$ & $\begin{array}{c}\text { Water extraction } \\
\text { and diversion } \\
\left(10^{8} \mathrm{t} / \mathrm{a}\right)\end{array}$ & $\begin{array}{c}\text { Soil and water } \\
\text { conservation } \\
\text { measures } \\
\left(10^{8} \mathrm{t} / \mathrm{a}\right)\end{array}$ & $\begin{array}{c}\text { Reservoir } \\
\text { siltation } \\
\left(10^{8} \mathrm{t} / \mathrm{a}\right)\end{array}$ \\
\hline 5.7 & 5.1 & 0.6 & 2.7 & 1.8 \\
\hline
\end{tabular}

large reservoirs had to tally deposited $89.44 \times 10^{8} \mathrm{~m}^{3}$, approximately $134.16 \times 10^{8} \mathrm{t}$ sediment, and the sediment deposition rate was about $2.80 \times 10^{8} \mathrm{t} / \mathrm{a}$.

Through the above analysis, we can roughly quantitatively estimate the impact of human activities on streamflow and sediment discharge reduction in the MRYR basin. Reduced cumulative streamflow was about $1740 \times 10^{8} \mathrm{~m}^{3}$, approximately $72.5 \times 10^{8} \mathrm{~m}^{3} / \mathrm{a}$ during 1986-2008; while reduced cumulative sediment discharge was about $154 \times 10^{8} \mathrm{t}$, approximately $5.7 \times 10^{8}$ t/a during 1982-2008. Reduced water and sediment affected by various human activities were estimated as follows: Reduced water was about $45 \times 10^{8} \mathrm{~m}^{3} / \mathrm{a}$, $10 \times 10^{8} \mathrm{~m}^{3} / \mathrm{a}$ and $6.0 \times 10^{8} \mathrm{~m}^{3} / \mathrm{a}$, respectively, due to water extraction and diversion, soil and water conservation measures, and evaporation and leakage losses (Table 10) (Gao, 2010). Reduced sediment was about $0.6 \times 10^{8} \mathrm{t} / \mathrm{a}$, $2.7 \times 10^{8} \mathrm{t} / \mathrm{a}$ and $1.8 \times 10^{8} \mathrm{t} / \mathrm{a}$, respectively, due to water extraction and diversion, soil and water conservation measures, and reservoir siltation (Table 11) (Gao, 2010).

\section{Summary and conclusion}

Precipitation, streamflow and sediment discharge during 1950-2008 were analysed by the Mann-Kendall trend test and the Pettitt's change-point analysis in the MRYR basin. Significant downward trends in annual precipitation $(P=0.05)$, annual streamflow $(P=0.01)$ and annual sediment discharge $(P=0.01)$ were detected in the MRYR basin.
The change-point or transition year was $1985(P=0.01)$ for streamflow, $1981(P=0.01)$ for sediment discharge in the MRYR basin.

Human intervention was largely responsible for the downward trends of streamflow and sediment discharge after the transition years in the MRYR basin. The effects of human intervention on streamflow and sediment discharge decline could be quantified by comparing the two periods using the double-mass curves. Compared to the period before the transition years, measured cumulative streamflow and sediment discharge decreased by $17.8 \%$ and $28 \%$, respectively, from the transition years to 2008 . Human activities played a major role in the streamflow and sediment discharge reduction. The average human activities contribution rate is $72.0 \%$ and $87.8 \%$ for the streamflow and sediment discharge reduction, which are significantly stronger than the precipitation contribution rate $(28.0 \%$ and $12.2 \%)$.

Soil and water conservation in the MRYR basin began in the late 1950s, and the pace was more than triple after the 1980s; the calculation was based on the areas conservation measures covered every year. The extensive adoption of conservation measures in the 1980s and 1990s altered the natural regimes of streamflow and led to an abrupt decline in streamflow in 1985, and the transition year of sediment discharge (1981) was also in good agreement with the period that conservation measures implemented. The rates of decreases in streamflow and sediment discharge coincided well with the intensity and extent of human intervention and activities. The overall results showed that human activities, such as soil and 
water conservation programmes, ecoenvironmental rehabilitation campaign, construction of key water control projects and so on, appear to be the major factor of a significant decrease in annual streamflow and sediment discharge in the recent 50 years in the MRYR basin.

Acknowledgements. This paper is financially supported by Programme KZCX2-XB2-05-03 and The National Basic Research Programme (also called 973 Programme) (2007CB407203).

Edited by: S. Grimaldi

\section{References}

Buishand, T. A.: Some methods for testing the homogeneity of rainfall records, J. Hydrol., 58(1-2), 11-27, 1982.

Burn, D. H. and Elnur, M. A.: Detection of hydrologic trends and variability, J. Hydrol., 255(1-4), 107-122, 2002.

Chen, J. and Gupta, A. K.: Parametric Statistical Change Point Analysis, Birkhauser, Boston, Massachusetts, USA, 240 pp., 2000.

Fu, G. B., Charles, S. P., Viney, N. R., Chen, S., and Wu, J. Q.: Impacts of climate variability on stream-flow in the Yellow River, Hydrol. Process., 21(25), 3431-3439, 2007.

Gao, P.: Streamflow and sediment discharge change trend and its response to human activities in the Middle Reaches of the Yellow River, Ph.D., Graduate University of the Chinese Academy of Sciences, China, 109 pp., 2010.

Gao, P., Mu, X. M., Li, R., and Wang, W.: Trend and driving force analyses of streamflow and sediment discharge in Wuding River, J. Sediment Res., (5), 22-28, 2009.

Gao, P., Zhang, X. C., Mu, X. M., Wang, F., Li, R., and Zhang, $X$. P.: Trend and change-point analyses of streamflow and sediment discharge in Yellow River mainstream during 1950-2005, Hydrolog. Sci. J., 55(2), 275-285, 2010.

Hirsch, R. M., Slack, J. R., and Smith, R. A.: Techniques of trend analysis for monthly water quality data, Water Resour. Res., 18, 107-121, 1982.

Huang, M. B. and Zhang, L.: Hydrological responses to conservation practices in a catchment of the Loess Plateau, China, Hydrol. Process., 18(10), 1885-1898, 2004.

Jenkins, G. M. and Watts, D. G.: Spectral Analysis and its Applications, Holden-Day, SanFrancisco, California, USA, 1968.

Kendall, M. G.: Rank Correlation Measures, Charles Griffin, London, UK, 202 pp., 1975.

Kulkarni, A. and von Storch, H.: Monte Carlo experiments on the effect of serial correlation on the Mann-Kendall test of trend, Meteorol. Z., 4(2), 82-85, 1995.

Lee, H. T.: Soil conservation in China's Loess Plateau, J. Soil Water Conserv., 39(5), 306-307, 1984.

Li, L. J., Zhang, L., Wang, H., Wang, J., Yang, J. W., Jiang, D. J., Li, J. Y., and Qin, D. Y.: As sessing the impact of climate variability and human activities on streamflow from the Wuding River basin in China, Hydrol. Process., 21(25), 3485-3491, 2007.

Liu, C. M. and Zhang, X. C.: Causal analysis on actual water flow reduction in the mainstream of the Yellow River, Acta Geographica Sinica, 59(3), 323-330, 2004.
Mann, H. B.: Nonparametric tests against trend, Econometrica, 13(3), 245-259, 1945.

Merriam, C. F.: A comprehensive study of the rainfall on the susquehanna valley, Trans. Amer. Geophys. Union, 18, 471-476, 1937.

Mu, X. M., Zhang, L., McVicar, T. R., Chille, B., and Gau, P.: Analysis of the impact of conservation measures on stream flow regime in catchments of the Loess Plateau, China, Hydrol. Process., 21(16), 2124-2134, 2007.

Mu, X. M., Zhang, X. Q., Gao, P., and Wang, F.: Theory of double mass curves and its applications in hydrology and meteorology, J. China Hydrology, 30(4), 47-51, 2010.

Pettitt, A. N.: A non-parametric approach to the change-point problem, Appl. Statist., 28(2), 126-135, 1979.

Radziejewski, M., Bardossy, A., and Kundzewicz, Z. W.: Detection of change in river flow using phase randomization, Hydrolog. Sci. J., 45(4), 547-558, 2000.

Ran, D. C.: Water and sediment variation and ecological protection measures in the middle reach of the Yellow River, Resources Science, 28(1), 93-100, 2006.

Siakeu, J., Oguchi, T., Aoki, T., Esaki, Y., and Jarvie, H. P.: Change in riverine suspended sediment concentration in central Japan in response to late 20th century human activities, Catena, 55(2), 231-254, 2004.

Searcy, J. K., Hardisoni, C. H., and Langbein, W.B.: Double mass curves. Geological Survey Water Supply Paper 1541-B, US Geological Survey, Washington, DC, 1960.

Tang, K. L.: The changes of erosion, runoff and sediment in the Yellow River, Science China Press, Beijing, China, 249 pp., 1993.

Tian, J. H., Cui, Q., Xu, J. H., and Zhou, X.: Surface-evaporation of large and middle reservoirs affects the cunount of water resource in the Yellow River valley, Journal of Shandong Agricultural University (Natural Science), 36(3), 391-394, 2005.

van den Elsen, E., Hessel, R., Liu, B. Y., Trouwborst, K. O., Stolte, J., Ritsema, C. J., and Blijenberg, H.: Discharge and sediment measurements at the outlet of a watershed on the Loess plateau of China, Catena, 54(1-2), 147-160, 2003.

von Storch, H. and Navarra, A. E.: Analysis of Climate Variability, Springer, New York, USA, 352 pp., 1995.

Wang, G. Q., Wu, B. S., and Wang, Z. Y.: Sedimentation problems and management strategies of Sanmenxia Reservoir, Yellow River, China, Water Resour. Res., 41, W09417, doi:10.1029/2004WR003919, 2005.

Wang, H. J., Yang, Z. S., Saito, Y., Liu, J. P., Sun, X. X., and Wang, Y.: Stepwise decreases of the Huanghe (Yellow River) sediment load (1950-2005): Impacts of climate change and human activities, Global Planet. Change, 57(3-4), 331-354, 2007.

$\mathrm{Xu}$, J. X.: Sediment flux to the sea as influenced by changing human activities and precipitation: example of the Yellow River, China, Environ. Manag., 31(3), 328-341, 2003.

Ye, Q. C. and Zuo, D. K.: Study on the laws of environmental change and water sediment transport in the Yellow River Basin, Shandong Science and Technology Press, Jinan, China, 1994.

Yu, L. S.: The Huanghe (Yellow) River: recent changes and its countermeasures, Cont. Shelf Res., 26(17-18), 2281-2298, 2006. 
Yue, S. and Pilon, P.: A comparison of the power of the t test, MannKendall and bootstrap tests for trend detection, Hydrolog. Sci. J., 49(1), 21-37, 2004.

Yue, S., Pilon, P., and Phinney, B.: Canadian streamflow trend detection: impacts of serial and cross-correlation, Hydrolog. Sci. J., 48(1), 51-63, 2003.
Zheng, H. X., Zhang, L., Liu, C. M., Shao, Q. X., and Fukushima, Y.: Changes in stream flow regime in headwater catchments of the Yellow River basin since the 1950s, Hydrol. Process., 21(6), 886-893, 2007. 